\title{
Breast-feeding duration and infant atopic manifestations, by maternal allergic status, in the first 2 years of life (KOALA study).
}

Citation for published version (APA):

Snijders, B. E., Thijs, C., Dagnelie, P. C., Stelma, F. F., Mommers, M., Kummeling, I., Penders, J., Van Ree, R., \& van den Brandt, P. A. (2007). Breast-feeding duration and infant atopic manifestations, by maternal allergic status, in the first 2 years of life (KOALA study). Journal of Pediatrics, 151(4), 347-351. https://doi.org/10.1016/j.jpeds.2007.03.022

Document status and date:

Published: 01/01/2007

DOI:

10.1016/j.jpeds.2007.03.022

Document Version:

Publisher's PDF, also known as Version of record

Please check the document version of this publication:

- A submitted manuscript is the version of the article upon submission and before peer-review. There can be important differences between the submitted version and the official published version of record.

People interested in the research are advised to contact the author for the final version of the publication, or visit the DOI to the publisher's website.

- The final author version and the galley proof are versions of the publication after peer review.

- The final published version features the final layout of the paper including the volume, issue and page numbers.

Link to publication

\footnotetext{
General rights rights.

- You may freely distribute the URL identifying the publication in the public portal. please follow below link for the End User Agreement:

www.umlib.nl/taverne-license

Take down policy

If you believe that this document breaches copyright please contact us at:

repository@maastrichtuniversity.nl

providing details and we will investigate your claim.
}

Copyright and moral rights for the publications made accessible in the public portal are retained by the authors and/or other copyright owners and it is a condition of accessing publications that users recognise and abide by the legal requirements associated with these

- Users may download and print one copy of any publication from the public portal for the purpose of private study or research.

- You may not further distribute the material or use it for any profit-making activity or commercial gain

If the publication is distributed under the terms of Article $25 \mathrm{fa}$ of the Dutch Copyright Act, indicated by the "Taverne" license above, 


\title{
Breast-Feeding Duration and Infant Atopic Manifestations, by Maternal Allergic Status, in the First 2 Years of Life (KOALA Study)
}

\author{
Bianca E. P. Snijders, MSc, Carel Thijs, MD, PhD, Pieter C. Dagnelie, PhD, Foekje F. Stelma, MD, PhD, \\ Monique Mommers, PhD, Ischa Kummeling, PhD, John Penders, PhD, Ronald van Ree, PhD, and \\ Piet A. van den Brandt, PhD
}

Objective To investigate the potential effect of modification by maternal allergic status on the relationship between breast-feeding duration and infant atopic manifestations in the first 2 years of life.

Study design Data from 2705 infants of the KOALA Birth Cohort Study (The Netherlands) were analyzed. The data were collected by repeated questionnaires at 34 weeks of gestation and 3, 7, 12, and 24 months postpartum. Total and specific immunoglobulin E measurements were performed on venous blood samples collected during home visits at age 2 years. Relationships were analyzed using logistic regression analyses.

Results Longer duration of breast-feeding was associated with a lower risk for eczema in infants of mothers without allergy or asthma $\left(P_{\text {trend }}=.01\right)$ and slightly lower risk in those of mothers with allergy but no asthma $\left(P_{\text {trend }}=.14\right)$. There was no such association for asthmatic mothers $\left(P_{\text {trend }}=.87\right)$. Longer breast-feeding duration decreased the risk of recurrent wheeze independent of maternal allergy $\left(P_{\text {trend }}=.02\right)$ or asthma status $\left(P_{\text {trend }}=.06\right)$.

Conclusions Our findings show that the relationship between breast-feeding and infant eczema in the first 2 years of life is modified by maternal allergic status. The protective effect of breast-feeding on recurrent wheeze may be associated with protection against respiratory infections. ( $J$ Pediatr 2007;151:347-51)

$\mathbf{T}$ he role of breast-feeding in allergic disease remains a matter of debate. The postulated protective effect of breast-feeding may act through several mechanisms. One possible mechanism is through the exclusion of potentially allergic components, like cow's milk or food products introduced in the infant's diet. Alternatively, breast-feeding provides the infant with immunomodulatory, anti-inflammatory, nutritional, and other components present in human breast milk.

Wright et $\mathrm{al}^{1}$ reported higher immunoglobulin $\mathrm{E}(\mathrm{IgE})$ levels in breast-fed children compared with never breast-fed children of mothers with high $\operatorname{IgE}$ levels. A study of Bavarian farmers study found an increased risk for doctor-diagnosed asthma related to breast-feeding in children whose mothers had asthma themselves. ${ }^{2}$ In children of asthmatic mothers, longer exclusive breast-feeding was found to be associated with a greater risk of asthma, but asthma was unrelated to feeding status in children without maternal asthma. ${ }^{3}$ In contrast, an Australian study found an association between exclusive breastfeeding and a statistically significant lower risk of asthma that was independent of maternal asthma and the child's atopic status. ${ }^{4}$

In the present study, we examined whether maternal allergy or asthma status is an effect modifier in the relationship between breast-feeding duration and the development of infant atopic manifestations (eczema, recurrent wheeze) in the first 2 years of life. We also studied the relationships between breast-feeding duration and increased total $\operatorname{IgE}$

\begin{tabular}{llll}
\hline $\mathrm{Cl}$ & Confidence interval & OR & Odds ratio \\
$\lg \mathrm{E}$ & Immunoglobulin $\mathrm{E}$ & UK-WP & UK Working Party \\
\hline
\end{tabular}

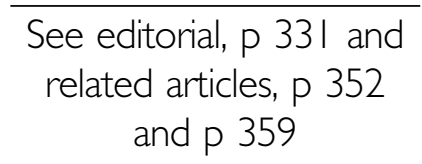

From the Care and Public Health Research Institute (CAPHRI) (B.S., C.T., M.M., I.K. P.V.) and Nutrition and Toxicology Research Institute Maastricht (NUTRIM) (C.T., P.D., J.P., P.vdB.), Department of Epidemiology, Maastricht University, Maastricht, The Netherlands; Department of Medical Microbiology, University Hospital of Maastricht, Maastricht, The Netherlands (F.S.); and Department of Experimental Immunology, Academic Medical Center, Amsterdam, The Netherlands (R.V.).

Supported by The Netherlands Organisation for Health Research and Development (Zon-Mw), program of Innovative Prevention Research (Prevention Program I, no. 210-00-090)

The sponsoring organization had no involvement in the study design, data collection, analysis, or interpretation, or in writing of the report or the decision to submit the manuscript for publication. There are no conflicts of interest to report.

Submitted for publication Aug 2, 2006; last revision received Dec 19, 2006; accepted Mar 15, 2007.

Reprint requests: Bianca Snijders, MSc, Department of Epidemiology, Maastricht University, PO Box 616, 6200 MD Maastricht, The Netherlands. E-mail: BEP. Snijders@EPID.unimaas.nl.

0022-3476/\$ - see front matter

Copyright (C) 2007 Mosby Inc. All rights reserved.

| 0.10 | 6/j.jpeds.2007.03.022 
levels and allergic sensitization at age 2 in children of mothers with and without increased total $\mathrm{IgE}$ levels or sensitization.

\section{METHODS}

\section{Study Population}

The study subjects were mother-infant pairs previously enrolled in the KOALA Birth Cohort Study between 2000 and $2002 . .^{5} \mathrm{We}$ recruited participants with diverse lifestyles ("conventional" and "alternative") who were at 34 weeks of gestation. The women with a conventional lifestyle ( $\mathrm{n}=$ 2343) were recruited from an ongoing prospective cohort study on pregnancy-related pelvic girdle pain in The Netherlands. The women with an alternative lifestyle $(n=491)$ were recruited through various channels, including organic food shops, anthroposophic doctors and midwives, Steiner schools, and magazines. The study design was approved by the Ethics Committee of Maastricht University, and all parents signed written informed consent.

\section{Data Collection}

During pregnancy and throughout the first 2 years of the child's life, information on breast-feeding, other determinants, and atopic manifestations was collected for all members of the cohort by repeated questionnaires at 34 weeks of gestation and at 3, 7, 12, and 24 months after birth. Home visits to children age 2 years by trained nurses to collect blood samples and perform clinical examination by trained nurses, using UK Working Party (UK-WP) criteria were started in September 2004.

All infants of participants $(n=2834)$ with a completed informed consent and the presence of the first questionnaire (34 weeks of gestation) were included in the study. We excluded infants with congenital diseases known to affect immunity, such as Down syndrome, and those with missing information on the main determinant, breast-feeding.

\section{Breast-Feeding Exposure}

Breast-feeding was categorized as follows, according to the age at which breast-feeding was stopped: never breast-fed (reference category), 0 to 3 months, 4 to 6 months, 7 to 9 months, and $>9$ months.

\section{Maternal Allergic History}

To study effect modification by maternal allergy or asthma on the relationship between breast-feeding duration and infant eczema and recurrent wheeze, we defined 3 strata: (1) no maternal allergy or asthma; (2) maternal allergy, no asthma, defined as self reported doctor's diagnosed eczema, allergy for house dust mite/pets, or allergic rhinoconjunctivitis (eg, hay fever); and (3) maternal asthma, defined as selfreported or physician-diagnosed asthma, irrespective of other allergic diseases. Maternal increased total $\mathrm{IgE}$ levels and sensitization were both defined as present (yes/no).

\section{Infant Atopic Manifestations}

Eczema (by Questionnaire, Adapted from International Study of Asthma and Allergies in Childhood).

In the 7-, 12-, and 24-month postpartum questionnaires, parents were asked: "Has your child ever had an itchy rash that came and went in the past months?" If the parent answered "yes" at least once, the infant was defined as having developed eczema in the first 2 years of life. Cases of diaper rash, rash around the eyes, or scalp scaling were excluded.

\section{Atopic Dermatitis (According to UK-WP Criteria)}

To specify eczema reported by parents as described earlier, we defined atopic dermatitis according to UK-WP criteria ${ }^{6}$ for all infants who were visited at home at age 2 years. In this study, infants with a UK-WP atopic dermatitis probability score $>0.9$ were considered as having probable presence of atopic dermatitis.

Recurrent wheezing in the first 2 years of life was defined as reported presence of wheezing with at least 4 attacks between age 0 and 7 months and mentioned in the 7 -month postpartum questionnaire, between age 7 and 12 months and mentioned in the 12 -month postpartum questionnaire, or between age 13 and 24 months and mentioned in the 24-month postpartum questionnaire.

\section{Measurements and Definitions of Allergic Sensitization (Mother and Infant)}

Maternal venous blood samples were obtained during home visits at 34 to 36 weeks of gestation. Infants' venous blood samples were obtained during home visits at 2 years postpartum. Total IgE levels were analyzed as described earlier. ${ }^{7,8}$ For values $<150 \mathrm{IU} / \mathrm{mL}$, a sandwich radioimmunoassay (RIA) was used; ${ }^{7}$ for values $>150 \mathrm{IU} / \mathrm{mL}$, a competitive RIA was used. ${ }^{8}$ All blood samples were analyzed for specific $\mathrm{IgE}$ against hen's eggs, cow's milk, peanuts, birch, grass pollen, cat, dog, and house dust mite using a radioallergosorbent test as described previously. ${ }^{8}$ Calculation was performed by means of a standard curve obtained by radioallergosorbent testing with a dilution series of a chimeric monoclonal $\operatorname{IgE}$ antibody against the major allergen Der p 2 and Sepharosecoupled recombinant Der p 2. ${ }^{9}$ The detection limits for total and specific $\mathrm{IgE}$ were $0.50 \mathrm{IU} / \mathrm{mL}$ and $0.10 \mathrm{IU} / \mathrm{mL}$, respectively. High maternal total $\mathrm{IgE}$ was arbitrarily defined as total IgE level $>100 \mathrm{IU} / \mathrm{mL}$; high total IgE for infants was arbitrarily defined as total $\mathrm{IgE}$ level $>10 \mathrm{IU} / \mathrm{mL}$. Mother and infant were considered sensitized if specific serum $\operatorname{IgE}$ levels were $>0.3 \mathrm{IU} / \mathrm{mL}$ against at least 1 of the food or inhalant allergens tested.

\section{Statistical Analysis}

Relationships were analyzed using logistic regression. Results are presented as unadjusted odds ratios (OR) and adjusted ORs with corresponding 95\% confidence intervals (CIs). All potential confounders were simultaneously included in the logistic regression model to adjust the analyses. 
Potential confounders were (1) age at introduction of cow's milk products, defined as artificial formulas (including hypoallergenic formulas), (raw) milk, porridge, yogurt, and other dairy products, categorized according to age at first introduction as 0 to 3 months, 4 to 6 months, 7 to 9 months, and after 9 months, and (2) age at introduction of other food products (eg, fruit mash), categorized according to the age at first introduction as 0 to 3 months, 4 to 6 months, and after 7 months. Other potential confounders were infant's sex, recruitment group (conventional/alternative lifestyle), antibiotic medication (yes/no), maternal smoking during pregnancy (yes/no), infant's exposure to environmental tobacco smoke (yes/no), maternal age at delivery, maternal education (primary school, preparatory vocational or lower general secondary education [low], vocational education, higher general secondary or pre-university education [middle], or higher vocational or academic education [high]), presence of paternal allergic disease (yes/no), number of siblings (no siblings, 1 sibling, or 2 or more siblings), and presence of older allergic siblings (no siblings, older allergic sibling[s], or older nonallergic sibling[s]).

To assess whether our results were prone to reverse causation (by introducing hypoallergenic formulas after the development of eczema), we explored the use of hypoallergenic formulas associated with atopic manifestations. For the test for trend, we repeated the logistic regression analyses with the categories of breast-feeding duration (coded as 1 to 5) as a continuous variable in the logistic regression analyses, again adjusting for all potential confounders. Effect modification by recruitment group was assessed using the likelihood ratio test, comparing models with and without interaction terms.

\section{RESULTS}

Of the 2834 infants enrolled at birth, 3 were excluded because of Down syndrome and 126 because of missing information on breast-feeding, leaving 2705 infants for the study. The response rate for the questionnaire at age 2 years was $93 \%(\mathrm{n}=2516)$. Home visits at age 2 years were made in 818 infants. Most infants were breast-fed ( $85 \% ; n=2287)$. Mothers in the alternative recruitment group had a higher rate and a longer duration of breast-feeding compared with those in the conventional recruitment group (Table I; available at www.jpeds.com). Also, they showed greater delay in the age of introduction of cow's milk products (Table I). Other characteristics that differed between both groups were maternal age, maternal smoking during pregnancy, environmental tobacco smoking, maternal education, number of siblings, and antibiotic medication use (Table I).

Infants receiving hypoallergenic formulas at any time between birth and age 3 months $(n=185)$ showed a higher risk of eczema in the first 2 years of life compared with infants given nonhypoallergenic formula feeding (unadjusted $\mathrm{OR}=$ $1.81 ; 95 \% \mathrm{CI}=1.31$ to 2.49 ) even when adjusting for all potential confounders (adjusted $\mathrm{OR}=1.97 ; 95 \% \mathrm{CI}=1.30$ to 3.00). Because these results may be explained by reverse causation (ie, hypoallergenic formulas were introduced after the development of eczema), we excluded the participants who introduced hypoallergenic formulas (0 to 3 months) from all subsequent analyses.

Overall, longer breast-feeding duration showed a statistically significant trend toward a lower risk of eczema $\left(P_{\text {trend }}=.03\right.$, adjusted for confounders $)$. Longer duration of breast-feeding was associated with a statistically significant lower risk for eczema in infants of mothers without allergy or asthma $\left(P_{\text {trend }}=.01\right.$; Table II). In mothers with allergy but no asthma, the results trended in the same direction but were not statistically significant $\left(P_{\text {trend }}=.14\right.$; Table II). For asthmatic mothers, there was no (inverse) association between breast-feeding duration and infant eczema $\left(P_{\text {trend }}=.87\right.$; Table II $)$. There was no association between breast-feeding duration and atopic dermatitis according to UK-WP criteria $(\mathrm{n}=866$; number of cases $=$ $117)$ in either the overall analysis or the 3 different maternal strata (results not shown; $P_{\text {trend }}>.05$ ).

Longer breast-feeding duration was associated with a lower risk of recurrent wheeze in infants of mothers with no allergy or asthma $\left(P_{\text {trend }}=.02\right)$, with allergy but no asthma $\left(P_{\text {trend }}=.02\right)$, and with asthma $\left(P_{\text {trend }}=.06\right)$. The breastfeeding category 7 to 9 months showed the lowest risk of infant recurrent wheeze in all groups $(\mathrm{OR}=0.11 ; 95 \% \mathrm{CI}=$ 0.02 to 0.70 ) (Table II).

Duration of breast-feeding did not influence the risk of high total $\mathrm{IgE}$ levels in infants of mothers who themselves had increased total $\mathrm{IgE}$ levels or in mothers with normal $\mathrm{IgE}$ levels (Table III; available at www.jpeds.com). Also, we found no association between breast-feeding duration and infant sensitization in infants of mothers with or without sensitization (Table III).

The differences in the ORs of unadjusted and adjusted analyses (Table II) were the result of strong confounding effects of a positive paternal history of allergic disease, age at introduction of cow's milk and other food products, and infant's use of antibiotics.

\section{DISCUSSION}

We found that longer duration of breast-feeding was associated with a decreased risk for recurrent wheeze in the first 2 years of life, regardless of the mother's allergy history. Moreover, longer duration of breast-feeding was associated with a decreased risk of eczema (by questionnaire) in infants of mothers without allergy or asthma. When atopic dermatitis (according to UK-WP criteria), increased total $\mathrm{IgE}$ levels, or sensitization were taken as the outcome, no associations with breast-feeding duration were found.

Overall, our results for eczema provide evidence of a protective effect of breast-feeding. We found a protective effect of breast-feeding duration on eczema in the first 2 years of life in mothers without allergy or asthma; this effect was less clear in mothers with allergy but no asthma and absent in mothers with maternal asthma. These findings imply effect modification by maternal allergic status for the relationship between breast-feeding and infant eczema. Nevertheless, 
Table II. Associations between breast-feeding duration and the development of infant eczema and recurrent wheeze during the first 2 years of life according to presence of allergy and/or asthma in the mother

\begin{tabular}{|c|c|c|c|c|c|c|c|c|}
\hline \multirow[b]{2}{*}{ Maternal status } & \multicolumn{4}{|c|}{ Infant eczema } & \multicolumn{4}{|c|}{ Infant recurrent wheeze } \\
\hline & $\mathbf{N}$ & n (\%) & OR $(95 \% \mathrm{Cl})$ & $\mathrm{OR}_{\mathrm{adj}}(95 \% \mathrm{Cl}) *$ & $\mathbf{N}$ & n (\%) & OR $(95 \% \mathrm{Cl})$ & $\mathrm{OR}_{\mathrm{adj}}(95 \% \mathrm{Cl}) *$ \\
\hline \multicolumn{9}{|l|}{$\begin{array}{c}\text { No allergy, no } \\
\text { asthma }\end{array}$} \\
\hline \multicolumn{9}{|l|}{$\mathrm{BF}$} \\
\hline Never & 231 & $61(26 \%)$ & 1.00 & 1.00 & 167 & $25(15 \%)$ & 1.00 & 1.00 \\
\hline 0 to 3 months & 494 & $132(27 \%)$ & $1.02(0.7 \mid$ to $\mid .45)$ & $0.90(0.61$ to 1.31$)$ & 353 & $55(16 \%)$ & $1.05(0.63$ to 1.75$)$ & I.II (0.62 to 2.00$)$ \\
\hline 4 to 6 months & 259 & $70(27 \%)$ & $1.03(0.69$ to 1.54$)$ & $0.7 \mathrm{I}(0.42$ to $\mathrm{I} .20)$ & 198 & $24(12 \%)$ & 0.78 (0.43 to I.43) & $0.84(0.36$ to 1.95$)$ \\
\hline 7 to 9 months & 245 & 74 (30\%) & $1.21(0.81$ to 1.80$)$ & $0.69(0.40$ to 1.19$)$ & 194 & $11(6 \%)$ & 0.34 ( 0.16 to 0.72$)$ & $0.37(0.14$ to 1.00$)$ \\
\hline$>9$ months & 309 & 75 (24\%) & 0.89 (0.60 to 1.32$)$ & 0.51 ( 0.29 to 0.89$)$ & 247 & $17(7 \%)$ & $0.42(0.22$ to 0.80$)$ & $0.43(0.16$ to 1.11$)$ \\
\hline$P_{\text {trend }}$ & & & .83 & .01 & & & .00 & .02 \\
\hline \multicolumn{9}{|l|}{$\begin{array}{r}\text { Maternal allergy, } \\
\text { no asthma }\end{array}$} \\
\hline \multicolumn{9}{|l|}{$\mathrm{BF}$} \\
\hline Never & 87 & $27(31 \%)$ & 1.00 & 1.00 & 67 & $15(22 \%)$ & 1.00 & 1.00 \\
\hline 0 to 3 months & 215 & 71 (33\%) & $1.10(0.64$ to 1.87$)$ & $0.90(0.52$ to 1.57$)$ & 139 & $22(16 \%)$ & $0.65(0.3 \mid$ to $\mid .36)$ & $0.56(0.25$ to 1.23$)$ \\
\hline 4 to 6 months & 111 & $43(39 \%)$ & $\mathrm{I} .4 \mathrm{I}(0.78$ to 2.54$)$ & $0.86(0.43$ to $I .7 I)$ & 84 & $13(16 \%)$ & 0.63 (0.28 to I. .45$)$ & $0.44(0.16$ to 1.26$)$ \\
\hline 7 to 9 months & 114 & $42(37 \%)$ & $1.30(0.72$ to 2.34$)$ & $0.68(0.34$ to 1.38$)$ & 89 & $6(7 \%)$ & 0.25 (0.09 to 0.69$)$ & $0.18(0.05$ to 0.61$)$ \\
\hline$>9$ months & 125 & $46(37 \%)$ & $1.29(0.72$ to 2.32$)$ & $0.63(0.31$ to 1.29$)$ & 101 & $10(10 \%)$ & 0.38 ( 0.16 to 0.91$)$ & $0.32(0.10$ to 1.00$)$ \\
\hline & & & .28 & .14 & & & .01 & .02 \\
\hline \multicolumn{9}{|l|}{ Maternal asthma } \\
\hline \multicolumn{9}{|l|}{$\mathrm{BF}$} \\
\hline Never & 27 & $7(26 \%)$ & 1.00 & 1.00 & 16 & $5(3 \mid \%)$ & 1.00 & 1.00 \\
\hline 0 to 3 months & 75 & $28(37 \%)$ & $1.70(0.64$ to 4.53$)$ & $1.39(0.51$ to 3.78$)$ & 47 & $13(28 \%)$ & 0.84 (0.24 to 2.89 ) & $0.40(0.10$ to $1.5 \mathrm{I})$ \\
\hline 4 to 6 months & 36 & $15(42 \%)$ & 2.04 (0.69 to 6.05$)$ & $1.40(0.44$ to 4.42$)$ & 24 & 7 (29\%) & 0.91 (0.23 to 3.58$)$ & $0.48(0.10$ to 2.32$)$ \\
\hline 7 to 9 months & 37 & $12(32 \%)$ & $1.37(0.46$ to 4.13$)$ & $0.70(0.22$ to 2.27$)$ & 24 & $3(13 \%)$ & 0.3 I (0.06 to I.57) & $0.11(0.02$ to 0.70$)$ \\
\hline$>9$ months & 42 & $22(52 \%)$ & $3.14(1.10$ to 9.00$)$ & $\mathrm{I} .67(0.53$ to $5.2 \mathrm{I})$ & 35 & $6(17 \%)$ & $0.46(0.12$ to 1.80$)$ & 0.22 (0.04 to 1.09$)$ \\
\hline$P_{\text {trend }}$ & & & .08 & .87 & & & .01 & .06 \\
\hline
\end{tabular}

May not add up to total numbers because of missing values.

$B F$, breast-feeding; $O R_{a d j}$, adjusted odds ratio.

*Based on logistic regression analysis adjusted for: the age at introduction of cow's milk products, the age at introduction other food products, infant sex, recruitment group, infant's use of antibiotics, maternal smoking during pregnancy, infant's exposure to environmental tobacco smoke, maternal age at delivery, maternal education, presence of paternal allergic disease, number of siblings and presence of older allergic siblings.

these results need to be interpreted with caution because only mothers without allergy or asthma who breast-fed for $>9$ months showed a statistically significantly lower risk for eczema in the first 2 years of life. In addition, the different results in the 3 maternal strata may be explained by differing reporting behaviors on symptoms of infant eczema between mothers with or without allergy and/or asthma.

Infants' eczema and sensitization were considered as separate outcomes instead of combining them as atopic eczema, because sensitized infants do not necessarily exhibit symptoms of eczema and vice versa. ${ }^{10}$ Consequently, we use the term "eczema" instead of "atopic eczema." On the other hand, we use the term "atopic dermatitis" for infants fulfilling the UK-WP criteria according to Williams et al. ${ }^{6}$ The associations between breast-feeding and eczema could not be confirmed by our results on atopic dermatitis according to the UK-WP criteria. We speculate that breast-feeding is associated only with a milder eczematous condition that has already disappeared at the time of the home visit. Another explanation for these discrepant findings is that the UK-WP criteria included specific predilection sites of atopic dermatitis (flexural involvement), ${ }^{6}$ whereas the questionnaire data were based on the presence of an itchy rash anywhere (except diaper rash, rash around the eyes, and scalp scaling), and thus may include nonatopic eczema.

Wright et $\mathrm{al}^{3}$ found an increased risk for asthma and wheeze in breast-fed children compared with never-breastfed children whose mothers had asthma themselves. Interestingly, the same authors also reported higher $\operatorname{IgE}$ levels in breast-fed versus never-breast-fed children of mothers with high IgE levels. ${ }^{1}$ In the present study, we found no effect of breast-feeding on total IgE levels in infants of mothers with or without high total $\mathrm{IgE}$ levels. We also found no effect of breast-feeding on sensitization in the infants of mothers with and without sensitization, suggesting no effect modification by maternal sensitization. We conclude that maternal atopic status is not a major effect modifier of the effect of breastfeeding on infants' atopic manifestations. However, it should be noted that total and specific IgE levels are only weakly associated with atopic eczema and wheeze. ${ }^{10}$ Allergic sensi- 
tization may not be a prerequisite for childhood eczema. ${ }^{11}$ An Australian study also showed no statistical interaction between breast-feeding and maternal asthma status for the risk of asthma in childhood. ${ }^{4}$

Our results indicate that longer breast-feeding duration protects against recurrent wheeze irrespective of maternal allergic status. Wright et $\mathrm{al}^{12}$ followed infants during regular visits to a health maintenance organization and found that in the first 4 months of life, any breast-feeding was associated with a decreased incidence of wheezing illnesses. Another study showed that breast-feeding for $\geq 6$ months was slightly protective against transient wheezing, whereas it was a moderate risk factor for late-onset wheezing. ${ }^{13}$ Wheezing in young children may represent a heterogeneous group of conditions. ${ }^{14}$ It is a relatively common symptom in infancy, and not all wheezing will necessarily become asthma in later life. We propose that our findings on recurrent wheeze actually reflect that breast-feeding protects against respiratory infections in early childhood. Indeed, infections have been found to be related to wheezing symptoms. For instance, Lemanske et $\mathrm{al}^{15}$ reported that in the first year of life, a virus could be found during a wheezing episode in $78 \%$ of severe wheezers and in $63 \%$ of mild wheezers. Earlier, Chantry et $\mathrm{al}^{16}$ found that full breast-feeding for $\geq 6$ months provided more protection against respiratory tract infection than full breast-feeding for $>4$ but $<6$ months.

There are several reasons why effect modification by maternal allergic status is important. First, it has been stated that a lack of stratification by maternal asthma and allergic predisposition in the child may have obscured how the relationship between breast-feeding and atopic manifestations changes with the child's age and atopic status. ${ }^{17}$ Second, the milk composition may differ in allergic and nonallergic mothers in such a way so as to affect atopic manifestations in the child. ${ }^{3}$ Not only cytokines, but also long-chain polyunsaturated fatty acid levels, may differ between atopic and nonatopic mothers. ${ }^{18-20}$

Taken together, we demonstrated that only the relationship between breast-feeding and infant eczema in the first 2 years of life may be modified by maternal allergic status, because a protective effect of breast-feeding duration on eczema seemed to be present mainly for mothers without allergy or asthma, after adjustment for confounders including age at introduction of cow's milk or other food products. The protective effect of breast-feeding against recurrent wheeze was observed irrespective of maternal allergic status, and we speculate that these results may reflect protection against respiratory illness.

\section{REFERENCES}

1. Wright AL, Sherrill D, Holberg CJ, Halonen M, Martinez FD. Breast-feeding, maternal $\mathrm{IgE}$, and total serum $\operatorname{IgE}$ in childhood. J Allergy Clin Immunol 1999;104:589-94.

2. Oberle D, Von Kries R, Von Mutius E. Asthma and breast-feeding. Thorax 2001;56:896.

3. Wright AL, Holberg CJ, Taussig LM, Martinez F. Material asthma status alters relation of infant feeding to asthma childhood. Adv Exp Med Biol 2000;478:131-7.

4. Oddy WH, Peat JK, de Klerk NH. Maternal asthma, infant feeding, and the risk of asthma in childhood. J Allergy Clin Immunol 2002;110:65-7.

5. Kummeling I, Thijs C, Penders J, Snijders BE, Stelma F, Reimerink J, et al. Etiology of atopy in infancy: the KOALA Birth Cohort Study. Pediatr Allergy Immunol 2005;16:679-84.

6. Williams HC, Burney PG, Hay RJ, Archer CB, Shipley MJ, Hunter JJ, et al. The UK Working Party's diagnostic criteria for atopic dermatitis. I. Derivation of a minimum set of discriminators for atopic dermatitis. Br J Dermatol 1994;131:383-96.

7. Stallman PJ, Aalberse RC. Estimation of basophil-bound $\operatorname{IgE}$ by quantitative immunofluorescence microscopy. Int Arch Allergy Appl Immunol 1977;54:9-18.

8. Aalberse RC, Koshte V, Clemens JG. Immunoglobulin $\mathrm{E}$ antibodies that crossreact with vegetable foods, pollen, and Hymenoptera venom. J Allergy Clin Immunol 1981;68:356-64

9. Schuurman J, Perdok GJ, Lourens TE, Parren PW, Chapman MD, Aalberse RC. Production of a mouse/human chimeric IgE monoclonal antibody to the house dust mite allergen Der $\mathrm{p} 2$ and its use for the absolute quantification of allergen-specific IgE. J Allergy Clin Immunol 1997;99:545-50.

10. Kusel MM, Holt PG, de Klerk N, Sly PD. Support for 2 variants of eczema. J Allergy Clin Immunol 2005;116:1067-72.

11. Williams H, Flohr C. How epidemiology has challenged 3 prevailing concepts about atopic dermatitis. J Allergy Clin Immunol 2006;118:209-13.

12. Wright AL, Holberg CJ, Martinez FD, Morgan WJ, Taussig LM. Breast-feeding and lower respiratory tract illness in the first year of life. Group Health Medical Associates. BMJ 1989;299:946-9.

13. Rusconi F, Galassi C, Corbo GM, Forastiere F, Biggeri A, Ciccone G, et al. Risk factors for early, persistent, and late-onset wheezing in young children. SIDRIA Collaborative Group. Am J Respir Crit Care Med 1999;160:1617-22.

14. Henderson J, North K, Griffiths M, Harvey I, Golding J. Pertussis vaccination and wheezing illnesses in young children: prospective cohort study. The Longitudinal Study of Pregnancy and Childhood Team. BMJ 1999;318:1173-6.

15. Lemanske RF, Jackson DJ, Gangnon RE, Evans MD, Li Z, Shult PA, et al. Rhinovirus illnesses during infancy predict subsequent childhood wheezing. J Allergy Clin Immunol 2005;116:571-7.

16. Chantry CJ, Howard CR, Auinger P. Full breast-feeding duration and associated decrease in respiratory tract infection in US children. Pediatrics 2006;117:425-32.

17. Wright AL, Holberg CJ, Taussig LM, Martinez FD. Factors influencing the relation of infant feeding to asthma and recurrent wheeze in childhood. Thorax 2001;56:192-7.

18. Bottcher MF, Jenmalm MC, Garofalo RP, Bjorksten B. Cytokines in breast milk from allergic and nonallergic mothers. Pediatric Res 2000;47:157-62.

19. Thijs C, Houwelingen A, Poorterman I, Mordant A, van den Brandt PA. Essential fatty acids in breast milk of atopic mothers: comparison with non-atopic mothers, and effect of borage oil supplementation. Eur J Clin Nutr 2000;54:234-8.

20. Duchen K, Yu G, Bjorksten B. Atopic sensitization during the first year of life in relation to long-chain polyunsaturated fatty acid levels in human milk. Pediatr Res 1998;44:478-84. 


\begin{tabular}{|c|c|c|c|c|c|c|}
\hline \multirow[b]{2}{*}{ Breast-feeding, n (\%) } & \multicolumn{2}{|c|}{$\begin{array}{c}\text { Conventional } \\
(\mathrm{n}=2229)\end{array}$} & \multicolumn{2}{|c|}{$\begin{array}{l}\text { Alternative } \\
(\mathrm{n}=476)\end{array}$} & \multicolumn{2}{|c|}{$\begin{array}{c}\text { Total } \\
(n=2705)\end{array}$} \\
\hline & & & & & & \\
\hline Never & 407 & $(18 \%)$ & II & $(2 \%)$ & 418 & $(16 \%)$ \\
\hline 0 to 3 months & 913 & $(41 \%)$ & 64 & $(13 \%)$ & 977 & $(36 \%)$ \\
\hline 4 to 6 months & 357 & $(16 \%)$ & 71 & $(15 \%)$ & 428 & $(16 \%)$ \\
\hline 7 to 9 months & 285 & $(13 \%)$ & 115 & $(24 \%)$ & 400 & $(15 \%)$ \\
\hline$>9$ months & 267 & $(12 \%)$ & 215 & $(45 \%)$ & 482 & $(18 \%)$ \\
\hline \multicolumn{7}{|c|}{ Age at introduction of cow's milk products, $n(\%)$} \\
\hline 0 to 3 months & 1016 & $(46 \%)$ & 51 & $(11 \%)$ & 1067 & $(39 \%)$ \\
\hline 4 to 6 months & 615 & $(29 \%)$ & 137 & $(29 \%)$ & 788 & $(29 \%)$ \\
\hline 7 to 9 months & 459 & $(21 \%)$ & 242 & $(51 \%)$ & 701 & $(26 \%)$ \\
\hline$>9$ months & 46 & $(2 \%)$ & 28 & $(6 \%)$ & 74 & $(3 \%)$ \\
\hline Unknown & 57 & $(3 \%)$ & 18 & $(4 \%)$ & 75 & $(3 \%)$ \\
\hline \multicolumn{7}{|l|}{ Use of hypoallergenic formulas, n (\%) } \\
\hline Yes & 163 & $(7 \%)$ & 22 & $(5 \%)$ & 185 & $(7 \%)$ \\
\hline \multicolumn{7}{|c|}{ Age at introduction of other foods products, $n(\%)$} \\
\hline 3 months & 178 & $(8 \%)$ & 20 & $(4 \%)$ & 198 & $(7 \%)$ \\
\hline 4 to 6 months & 1846 & $(83 \%)$ & 411 & $(86 \%)$ & 2257 & $(83 \%)$ \\
\hline$\geq 7$ months & 48 & $(2 \%)$ & 27 & $(6 \%)$ & 75 & $(3 \%)$ \\
\hline Unknown & 157 & $(7 \%)$ & 18 & $(4 \%)$ & 175 & $(7 \%)$ \\
\hline Sex of infants, no of boys (\%) & 1133 & $(51 \%)$ & 240 & $(50 \%)$ & 1373 & $(51 \%)$ \\
\hline Maternal age in years, mean (SD) & 31 & (4) & 34 & (4) & 32 & (4) \\
\hline Maternal smoking during pregnancy, n (\%) & 189 & $(9 \%)$ & 3 & $(1 \%)$ & 192 & $(7 \%)$ \\
\hline Environmental tobacco smoking, n (\%) & 110 & $(5 \%)$ & 2 & $(<1 \%)$ & 112 & $(4 \%)$ \\
\hline \multicolumn{7}{|l|}{ Maternal education, n (\%) } \\
\hline Low & 256 & $(12 \%)$ & 18 & $(4 \%)$ & 274 & $(10 \%)$ \\
\hline Middle & 857 & $(39 \%)$ & 83 & $(17 \%)$ & 940 & $(35 \%)$ \\
\hline High & 993 & $(45 \%)$ & 362 & $(76 \%)$ & 1355 & $(50 \%)$ \\
\hline Unknown & 123 & $(6 \%)$ & 13 & $(3 \%)$ & 136 & $(5 \%)$ \\
\hline \multicolumn{7}{|l|}{ Parental allergic disease, n (\%) } \\
\hline Both parents nonallergic & 878 & $(40 \%)$ & 186 & $(40 \%)$ & 1064 & $(39 \%)$ \\
\hline Only father allergic & 460 & $(21 \%)$ & 110 & $(23 \%)$ & 570 & $(21 \%)$ \\
\hline Only mother allergic & 496 & $(22 \%)$ & 105 & $(22 \%)$ & 601 & $(22 \%)$ \\
\hline Both parents allergic & 288 & $(13 \%)$ & 69 & $(15 \%)$ & 357 & $(13 \%)$ \\
\hline Unknown & 107 & $(5 \%)$ & 6 & $(1 \%)$ & 113 & $(4 \%)$ \\
\hline \multicolumn{7}{|l|}{ Number of siblings, $n(\%)$} \\
\hline 0 siblings & 1804 & $(81 \%)$ & 369 & $(78 \%)$ & 2173 & $(80 \%)$ \\
\hline I sibling & 286 & $(13 \%)$ & 81 & $(17 \%)$ & 367 & $(14 \%)$ \\
\hline 2 or more siblings & 42 & $(2 \%)$ & 22 & $(5 \%)$ & 64 & $(2 \%)$ \\
\hline Unknown & 97 & $(4 \%)$ & 4 & $(1 \%)$ & 101 & $(4 \%)$ \\
\hline \multicolumn{7}{|l|}{ Presence of older allergic siblings, $n$ (\%) } \\
\hline No siblings & 1804 & $(81 \%)$ & 369 & $(78 \%)$ & 2173 & $(80 \%)$ \\
\hline Older nonallergic sibling(s) & 249 & $(13 \%)$ & 71 & $(15 \%)$ & 320 & $(12 \%)$ \\
\hline Older allergic sibling(s) & 85 & $(2 \%)$ & 35 & $(7 \%)$ & 120 & $(4 \%)$ \\
\hline Unknown & 91 & $(4 \%)$ & I & $(<1 \%)$ & 92 & $(3 \%)$ \\
\hline \multicolumn{7}{|l|}{ Infant's use of antibiotics, n (\%) } \\
\hline Yes & 430 & $(19 \%)$ & 56 & $(12 \%)$ & 486 & $(18 \%)$ \\
\hline Unknown & 187 & $(8 \%)$ & 15 & $(3 \%)$ & 202 & $(8 \%)$ \\
\hline
\end{tabular}

$S D$, standard deviation.

*Numbers may not add up to the total because of missing values. 
Table III. Associations between breast-feeding duration and infant increased total IgE and sensitization at age 2 years, according to presence of increased total IgE/sensitization in the mother

\begin{tabular}{|c|c|c|c|c|c|c|c|c|c|}
\hline \multirow[b]{2}{*}{ Maternal status } & \multicolumn{4}{|c|}{ Infant increased total IgE } & & \multicolumn{4}{|c|}{ Infant sensitization } \\
\hline & $\mathbf{N}$ & n (\%) & OR $(95 \% \mathrm{CI})$ & OR $_{\mathrm{adj}}(95 \% \mathrm{CI})$ & & $\mathbf{N}$ & n (\%) & OR $(95 \% \mathrm{Cl})$ & OR $_{\mathrm{adj}}(95 \% \mathrm{Cl})$ \\
\hline $\begin{array}{l}\text { Maternal total } \lg \mathrm{E} \leq \mathrm{I} 00 \\
\mathrm{IU} / \mathrm{mL}\end{array}$ & & & & & $\begin{array}{l}\text { No maternal } \\
\text { sensitization }\end{array}$ & & & & \\
\hline \multicolumn{10}{|l|}{$\mathrm{BF}$} \\
\hline Never & 68 & $24(35 \%)$ & 1.00 & 1.00 & Never & 52 & II (2I\%) & 1.00 & 1.00 \\
\hline 0 to 3 months & 150 & $70(47 \%)$ & 1.60 (0.89 to 2.90$)$ & I.8I (0.95 to 3.46$)$ & 0 to 3 months & 97 & $23(24 \%)$ & $\mathrm{I} .35$ (0.56 to 3.25$)$ & $1.35(0.53$ to 3.43$)$ \\
\hline 4 to 6 months & 124 & $75(61 \%)$ & 2.81 (1.52 to 5.19$)$ & $2.34(0.93$ to 5.93$)$ & 4 to 6 months & 81 & $26(32 \%)$ & 1.52 (0.60 to 3.82$)$ & $2.03(0.60$ to 6.88$)$ \\
\hline 7 to 9 months & 117 & $63(54 \%)$ & 2.14 ( 1.16 to 3.96$)$ & I.7I (0.65 to 4.45$)$ & 7 to 9 months & 74 & $17(23 \%)$ & $\mathrm{I} .80$ (0.74 to 4.39$)$ & $2.72(0.80$ to 9.25$)$ \\
\hline$>9$ months & 142 & $85(60 \%)$ & 2.73 ( 1.50 to 4.98$)$ & 1.80 (0.67 to 4.82$)$ & $>9$ months & 91 & $22(24 \%)$ & 0.98 (0.39 to 2.48$)$ & $1.59(0.45$ to 5.66$)$ \\
\hline $\begin{array}{l}P_{\text {trend }} \\
\text { Maternal total lgE }>100 \\
\qquad \mathrm{IU} / \mathrm{mL}\end{array}$ & & & .00 & .65 & $\begin{array}{l}P_{\text {trend }} \\
\text { Maternal } \\
\quad \text { sensitization }\end{array}$ & & & 1.00 & .80 \\
\hline \multicolumn{10}{|l|}{$\mathrm{BF}$} \\
\hline Never & 21 & $10(48 \%)$ & 1.00 & 1.00 & Never & 35 & $9(26 \%)$ & 1.00 & 1.00 \\
\hline 0 to 3 months & 37 & $20(54 \%)$ & $\mathrm{I} .29(0.44$ to 3.78$)$ & 1.34 (0.43 to 4.19$)$ & 0 to 3 months & 88 & $28(32 \%)$ & $\mathrm{I} .16(0.5 \mathrm{I}$ to $2.6 \mathrm{I})$ & $1.35(0.57$ to 3.18$)$ \\
\hline 4 to 6 months & 18 & II (6I\%) & $\mathrm{I} .75(0.49$ to 6.30$)$ & $1.49(0.34$ to 6.64$)$ & 4 to 6 months & 61 & 21 (34\%) & $\mathrm{I} .76(0.78$ to 3.97$)$ & $2.86(0.91$ to 8.92$)$ \\
\hline 7 to 9 months & 29 & $15(52 \%)$ & 1.19 (0.39 to 3.68$)$ & $0.88(0.22$ to 3.45$)$ & 7 to 9 months & 73 & $28(38 \%)$ & I.II (0.47 to 2.62$)$ & 1.91 (0.58 to 6.25$)$ \\
\hline$>9$ months & 23 & 19 (83\%) & 5.21 ( 1.32 to 20.67$)$ & $4.66(0.94$ to 23.18$)$ & $>9$ months & 71 & I 8 (25\%) & $\mathrm{I} .19$ (0.52 to 2.70$)$ & 2.39 ( 0.72 to 7.96$)$ \\
\hline$P_{\text {trend }}$ & & & .05 & .31 & $P_{\text {trend }}$ & & & .85 & .50 \\
\hline
\end{tabular}

May not add up to total numbers because of missing values.

$B F$, breastfeeding.

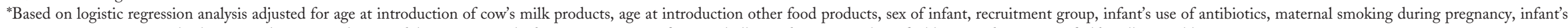
exposure to environmental tobacco smoke, maternal age at delivery, maternal education, presence of paternal allergic disease, number of siblings, and presence of older allergic siblings. 